\title{
PROFIL STRATEGI PEMBELAJARAN BAHASA JEPANG DI LPK TERAKOYA BALI
}

\author{
I. K. W. Astina, G. S. Hermawan, D. M. S. Mardani \\ Program Studi Pendidikan Bahasa Jepang \\ Universitas Pendidikan Ganesha \\ Singaraja \\ e-mail: astina0701@gmail.com \\ satya.hermawan@undiksha.ac.id desak.mardani@undiksha.ac.id
}

\begin{abstract}
Abstrak
Penelitian ini bertujuan untuk mendeskripsikan, (1) strategi yang digunakan dalam pembelajaran bahasa Jepang di LPK Terakoya, (2) faktor-faktor yang mendasari penggunaan strategi dalam pembelajaran bahasa Jepang di LPK Terakoya. Subjek penelitian pada penelitian ini adalah pengajar bahasa Jepang di LPK Terakoya Bali. Pengumpulan data dilakukan dengan metode observasi, wawancara, dan dokumentasi, kemudian dianalisis dengan metode deskriptif kualitatif. Hasil penelitian ini menunjukkan bahwa (1) strategi yang digunakan oleh guru dalam pembelajaran bahasa Jepang di LPK Terakoya yaitu strategi drill, tanya jawab dan role play, (2) faktor-faktor yang mendasari pemilihan strategi pembelajaran di LPK Terakoya yaitu faktor kurangnya keberanian siswa dalam berbicara dan tuntutan pembelajaran yang mengharuskan siswa menguasai bahasa Jepang dengan cepat dalam jenjang waktu yang singkat.
\end{abstract}

Kata Kunci : Profil, Strategi Pembelajaran, Pembelajaran di LPK.

\section{要旨}

本研究の目的は(1) テラコヤ・バリ技能訓練協会における日本語学習の ストラテジ一を 明らかにすることである、(2)テラコヤ・バリ技能訓練協会における日本語学習のストラテジ一を使用 寸る要因を明らかにすることである。調查対象はテラコヤ・バリ技能訓練協会の 日本語教師である。

データ収集方法は見学、インタビュー、及び文章化である。そ扎を定性的な記述法により分析した。 調查結果は使用した ストラテジ一は 教練、質疑応答、又はロールプレイである、(2) 使用した要因は学習者に短時間で日本語を身につけさせるからである。

キーワード：プロフィール、授業のストラテジー、テラコヤ・バリ技能訓練協会の学習 


\section{Pendahuluan}

Pendidikan bahasa Jepang di Indonesia umumnya diselenggarakan pada sekolah menengah, perguruan tinggi, dan pada kursus-kursus. Minat pembelajar bahasa Jepang dari tahun ke tahun terus bertambah, baik dari jumlah pembelajarnya maupun lembaga penyelenggarannya. Saat ini pembelajar bahasa Jepang didominasi oleh siswa SMA yang mendapatkan pelajaran bahasa asing karena didukung oleh kurikulum yang ada. Namun kemajuan perindustrian Jepang membangun antusias masyarakat umum sengaja belajar bahasa Jepang dengan tujuan bekerja di Jepang.

Seorang yang berminat berangkat ke Jepang untuk tujuan bekerja harus dibekali dengan kemampuan berbahasa Jepang yang baik. Nugraha (2013:2) menyatakan "suatu proses pendidikan dan pelatihan baik yang diselenggarakan oleh lembaga penyalur tenaga kerja pemerintah maupun swasta sangat diperlukan dalam pemenuhan kompetensi dan kualitas SDM calon tenaga kerja luar negeri". Keadaan seperti ini mendorong banyaknya berdiri lembaga yang menawarkan

pelatihan atau kursus bahasa Jepang dengan tujuan menciptakan calon tenaga kerja yang siap untuk magang di Jepang.

Dari data yang diperoleh dari JITCO (Japan International Training Cooperation Organization) tahun 2016, ada 21 LPK (lembaga pelatihan kerja) yang ada di Bali. Diantaranya LPK Japan Indonesia Asaori (Jembrana), LPK Bistra Kenshu senta (Jembrana), LPK Bulan Palapa (Bangli), LPK Citra Sula Dewi (Denpasar), LPK Darma (Denpasar), LPK Dwipayana Cipta Karya (Gianyar), LPK Duta Sahaya (Tabanan), LPK Dwipahara (Bangli), LPK Ganesha Karya Abadi (Denpasar), LPK Hishou Universal Style (Bangli), LPK Higa Nusantara Jaya (Jembrana), LPK Japan Rich (Karangasem), LPK Karunia Dewata (Badung), LPK Lintas Negeri (Jembrana), LPK LPJ Bali (Denpasar), LPK PT. Mitra Bahari Indonesia (Denpasar), LPK Sakura Artha Bhuwana denpasar, LPK Salunglung (Denpasar), LPK Sinar Terang Bersatu (Denpasar), LPK Swasta Training Centre (Karangasem), LPK World Training Centre (Karangasem) dan LPK Terakoya (Badung). Dari 21 LPK yang ada di Bali, LPK Terakoya menjadi pilihan untuk melakukan penelitian.

Hal yang menjadi alasan LPK Terakoya menjadi tempat pilihan untuk melakukan penelitian ini yaitu dari sekian LPK yang ada di Bali khususnya di daerah Denpasar dan Badung, LPK Terakoya Tergolong LPK yang banyak diminati. Dari 4 kelas yang ada di LPK Terakoya, jumlah siswa yang terdaftar disetiap kelas mencapai 20 orang. LPK Terakoya berdiri tahun 2013, namun hingga sekarang sudah memberangkatkan kurang lebih 79 orang untuk bekerja di perindustrian, peternakan, perkebunan dan kontruksi di Jepang. LPK Terakoya sudah terakreditasi dan memiliki kerjasama dengan koperasi-koperasi penyalur tenaga kerja yang ada di Jepang. Kerjasama ini mempermudah LPK Terakoya menyalurkan tenaga kerja sesuai kebutuhan-kebutuhan perusahaan yang ada di Jepang. Selain itu, karena pelatihan yang dilaksanakan selama empat bulan, maka para pengajar merancang modul tersendiri sesuai kebutuhan dari peserta magang di LPK Terakoya.

LPK Terakoya memiliki dua modul yang digunakan untuk mengajar selama empat bulan. Modul pertama, digunakan selama satu bulan dan modul yang kedua digunakan selama tiga bulan selanjutnya. Modul di LPK terakoya dibedakan karena modul pertama berisikan materi pembelajaran bahasa Jepang dasar, seperti aisatsu (perkenalan), pengenalan hari, bulan, tanggal dan pengenalan huruf hiragana katakana. Sedangkan modul yang kedua berisikan materi mengenai penguasaan pola kalimat atau tata bahasa (Bunpou). Pengajar di LPK Terakoya tidak menggunakan rancangan rencana pembelajaran (RPP), namun pengajar di LPK Terakoya mengajar dengan panduan silabus yang dirancang sesuai kebutuhan siswa dan tanpa berpatokan pada kurikulum. Dibalik silabus dan modul yang dirancang sendiri oleh para pengajar, tentu ada strategi mengajar yang mendukung demi tercapainya tujuan pembelajaran tersebut. Sehingga menarik untuk diketahui strategi yang digunakan oleh pengajar di LPK Terakoya.

Penelitian mengenai profil pembelajaran di LPK sudah pernah dilaksanakan oleh Sudarma (2015) penelitian berfokus di LPK Duta Sahaya Tabanan Bali yang meneliti tentang 
metode pembelajaran bahasa Jepang yang digunakan dan bagaimana variasi metode yang digunakan pada saat pembelajaran di LPK Duta Sahaya. Namun LPK Duta Sahaya masih berpedoman pada buku ajar "Minna Nihongo" yang merupakan buku ajar yang umum digunakan pada setiap lembaga pengajaran bahasa Jepang. Sedangkan LPK Terakoya sudah memiliki modul yang sesuai dengan kompetensi yang di butuhkan oleh peserta magang. Selain itu, penelitian yang Sudarma lakukan di LPK Duta Sahaya sudah tergolong lama. Mengingat semakin berkembangnya sistem pembelajaran tentunya ada perubahan dalam proses pengajarannya. LPK Terakoya tergolong LPK muda yang ada di Bali, dengan modul yang dirancang sesuai kebutuhan peserta magang dan berkembangnya sistem pembelajaran tentu ada strategi yang mendukung yang digunakan oleh para pengajar demi tercapainya tujuan dari LPK Terakoya.

Penelitian yang relevan kedua dilakukan oleh Ricad (2013). Penelitian tersebut tentang Pengelolaan LPK Chinju Dalam Penyelenggaraan Kursus Bahasa Korea di Kota Bengkulu. Menggunakan metode penelitian observasi, wawancara dan dokumentasi. Pada peneitian ini membahas bagaimana cara penentuan materi serta tutor dalam pembelajaran di LPK Chinju Bengkulu. Sedangkan dalam proses pembelajaran selain tutor dan materi pembelajaran, strategi pembelajaran merupakan hal yang penting untuk tercapainya tujuan pembelajaran. Sehingga penelitian di LPK Terakoya ini lebih memfokuskan penelitian pada strategi yang digunakan oleh pengajar di LPK Terakoya.

Penelitian yang relevan selanjutnya dilakukan oleh Tarasaka (2018). Penelitian ini membahas mengenai strategi apa yang digunakan oleh guru dalam praktik sehari-hari, pengamatan perilaku guru untuk mengelola pembelajaran dan perilaku anak-anak di ruang kelas di sekolah dasar Jepang. Pengklasifikasian 485 deskripsi perilaku guru yang diamati dan mengidentifikasi 22 strategi, yang selanjutnya diklasifikasikan ke dalam empat kategori: pengajaran, strategi proaktif, penguatan perilaku positif, dan respons reaktif terhadap perilaku yang tidak pantas. Hasilnya menunjukkan bahwa strategi mengelola kelas yang diidentifikasi sesuai dengan yang ada dalam literatur dan guru di sekolah dasar menggunakan strategi yang lebih reaktif. Penelitian tersebut berfokus pada strategi pengelolaan kelas pada anak-anak di sekolah dasar. Sedangkan penelitian ini memfokuskan pada strategi yang digunakan pengajar dalam mengembangkan kemampuan berbahasa siswa di LPK Terakoya.

Pada hal ini penulis meneliti profil LPK Terakoya Bali dalam mencetak tenaga kerja yang berkualitas dan mampu bersaing. Dalam penelitian ini akan dijelaskan mengenai strategi pembelajaran bahasa Jepang di LPK Terakoya Bali, faktor yang mendasari pengunaan strategi pembelajaran bahasa Jepang di LPK Terakoya, kendala-kendala dalam pembelajaran bahasa Jepang di LPK Terakoya. Penelitian tentang LPK Terakoya akan berimplikasi pada pengetahuan tentang pembelajaran bahasa Jepang khusus sesuai dengan visi lembaga yaitu mencetak angkatan kerja muda Indonesia yang memiliki semangat kerja dan disiplin yang tinggi, berkualitas, kompetensi, kreatif dan inovatif sehingga dapat membantu peningkatan perekonomian dan perindustrian di Indonesia.Berdasarkan uraian latar belakang yang telah dipaparkan di atas, maka rumusan masalah yang didapat sebagai berikut: (1) Apa strategi yang digunakan dalam pembelajaran bahasa Jepang di LPK Terakoya?; (2)Apa faktor yang mendasari penggunaan strategi pembelajaran tersebut dalam proses pembelajaran bahasa Jepang di LPK Terakoya?; dan (3) Apa saja kendala yang di hadapi oleh pengajar di LPK Terakoya?

Pada penelitian ini menggunakan bebarapa landasan teori seperti: (1) Pendidikan Formal; (2) Pendidikan Non Formal; (3) Hakikat Pembelajaran Bahasa Asing; (4) Strategi Pembelajaran Bahasa Asing; dan (5) Kendala-kendala dalam pembelajaran.

Pendidikan bukan sekedar usaha pemberian informasi dan keterampilan tetapi diperluas ruang lingkupnya sehingga mencakup usaha mewujudkan kehidupan pribadi sosial yang memuaskan. Menurut Undang-Undang No 20 Tahun 2003 pendidikan formal didefinisikan sebagai jalur pendidikan yang terstruktur dan berjenjang yang terdiri atas pendidikan dasar, penddikan menengah, dan pendidikan tinggi. Menurut definisi diatas dapat disimpulkan, pendidikan di Indonesia dapat dilaksanakan dalam dua jalur yaitu pendidikan 
formal dan non formal. Melalui jalur pendidikan formal seseorang dapat menempuh pendidikan dasar yaitu SD dan SMP, pendidikan menengah yaitu SMA dan tinggi yaitu perpengajaran tinggi.

Menurut Joesoef (2008) pendidikan non formal adalah setiap kesempatan dimana terdapat komunikasi yang terarah di luar sekolah dan seseorang memperoleh informasi, pengetahuan, latihan maupun bimbingan sesuai dengan tingkat usia dan kebutuhan hidup, dengan tujuan mengembangkan tingkat keterampilan, sikap dan nilai-nilai yang memungkinkan baginya menjadi peserta-peserta yang efesien dan efektif dalam lingkungan keluarga, pekerjaan bahkan lingkungan masyarakat dan negaranya. Dari beberapa definisi diatas dapat disimpulkan bahwa pendidikan non formal adalah pendidikan kegiatan belajar mengajar yang diadakan di luar sekolah untuk memenuhi kebutuhan pendidikan peserta didik tertentu untuk mendapatkan informasi, pengetahuan, latihan, dan bimbingan sehingga mampu bermanfaat bagi keluarga, masyarakat, dan negara.

Pembelajaran bahasa Jepang sebagai salah satu mata pelajaran berbahasa asing selain bahasa Inggris. Parera (1993:16) menyatakan bahasa asing (dalam pembelajaran bahasa) adalah bahasa selain bahasa ibu yang sedang dipelajari oleh peserta didik, dimana bahasa asing tersebut belum dikenal oleh peserta didik. Apabila bahasa asing tersebut dipelajari disekolah, maka bahasa asing tersebut menjadi bahasa ajaran. Jadi bahasa asing dalam lingkup pendidikan adalah bahasa yang baru pertama kali dikenal oleh peserta didik melalui pendidikan formal atau melalui proses belajar mengajar, dimana pembelajaran bahasa asing ini nantinya digunakan sebagai alat berinteraksi dan berkomunikasi.

David dalam (Sanjaya, 2012:126) menyatakan dalam dunia pendidikan, strategi diartikan sebagai a plan, method, or series of activities designed to achieves a particular educational goal artinya strategi adalah sebuah perencanaan yang berisi tentang rangkaian kegiatan yang didesain untuk mencapai tujuan pendidikan tertentu. Demikian juga halnya dalam proses pembelajaran, untuk mencapai tujuan pembelajaran perlu disusun suatu strategi agar tujuan itu tercapai secara optimal. Ada beberapa strategi pembelajaran yaitu strategi roleplay, drill, dan tanya jawab.

Dalam proses pengajaran terkadang terdapat kendala, hambatan atau masalah yang dihadapi pengajar. Hamalik (dalam Zulpah,2012:33) terdapat 3 jenis faktor utama penyebab dari terjadinya hambatan tersebut, diantaranya : (1) faktor manusiawi, seperti: pengajar kurang mampu atau kurang berminat, siswa kurang mampu dalam mengikuti pelajaran, siswa berbeda satu sama lain. (2) Faktor institusional, seperti: terbatasnya ruang kelas, ruangan praktek laboratorium. (3) Faktor instruksional, seperti: terbatasnya alat peraga atau media pembelajaran.

\section{Metode}

Penelitian ini bersifat kualitatif. Artinya data yang digunakan merupakan data kualitatif (data yang tidak terdiri atas angka-angka) yang bersifat deskriptif. Rancangan penelitian diperlukan untuk merencanakan suatu kegiatan yang akan dilaksanakan. (Wendra, 2013) dalam bukunya mengartikan rancangan penelitian sebagai suatu strategi dalam mengatur latar (setting) penelitian agar peneliti mendapatkan data yang tepat sesuai dengan karakteristik variabel dan tujuan penelitian. Fokus penelitian ini adalah strategi pembelajaran bahasa Jepang pada LPK Terakoya Bali. Strategi pembelajaran ini dilihat dari segi strategi apa yang digunakan, faktor yang mendasari penggunaan strategi tersebut dan kendala yang dialami dalam proses pembelajaran di LPK Terakoya.Penelitian ini dibedakan menjadi beberapa tahapan. Tahap pertama adalah tahap persiapan atau observasi awal, selanjutnya penyusunan instrument, tahap ketiga adalah pengumpulan data. Setelah data terkumpul, kemudian dideskripsikan dan terakhir dilaksanakan pelaporan hasil penelitian. Dalam tahap persiapan, peneliti melakukan observasi awal untuk melihat situasi di LPK Terakoya Bali sekaligus meminta ijin untuk melaksanakan penelitian. Peneliti juga menetapkan subjek penelitian dimana dalam hal ini adalah proses pembelajaran di LPK Terakoya Bali. Selanjutnya dilaksanakan penyusunan instrumen. Instrumen yang digunakan 
yaitu pedoman wawancara dan catatan harian. Pengumpulan data dan mendeskripsikan data, dilakukan melalui observasi dan wawancara.

Penelitian ini dilaksanakan di LPK Terakoya Jimbaran Bali. Penelitian mengambil lokasi di LPK Terakoya Bali karena lembaga pelatihan kerja ini belum pernah dikaji dan lembaga ini merupakan salah satu lembaga swasta resmi di Bali yang memberikan pembelajaran bahasa Jepang sekaligus peluang bekerja ke Jepang.

Subjek penelitian adalah benda, hal atau orang tempat variabel melekat dan yang dipermasalahkan (Arikunto, 1998:2). Subyek penelitian mempunyai kedudukan yang sangat sentral dalam penelitian karena pada subyek itulah data tentang variable yang diteliti berada dan diamati oleh peneliti. Pada umumnya, peneliti menginginkan agar subyek penelitian ini agak besar atau benyak, agar data diperoleh cukup banyak pula. Subjek dalam penelitian ini adalah pengajar bahasa Jepang di LPK Terakoya Bali. Dalam penelitian ini, penulis mengobservasi 3 (tiga) orang pengajar Bahasa Jepang di LPK Terakoya Bali. Objek penelitian adalah sasaran yang akan diteliti. Dalam penelitian ini, yang menjadi objek penelitian adalah (1) strategi guru-guru dalam pembelajaran bahasa Jepang di LPK Terakoya Bali, (2) faktor-faktor yang mendasari penggunaan strategi tersebut dalam pembelajaran bahasa Jepang di LPK Terakoya Bali, dan (3) Kendala-kendala yang dihadapi pengajar dalam pembelajaran bahasa Jepang di LPK Terakoya Bali.

Metode yang dipakai dalam pengumpulan data dalam penelitian ini, adalah teknik non tes yaitu metode observasi, wawancara, dan dokumentasi. Instrumen yang digunakan adalah catatan harian dan pedoman wawancara.Metode ini secara langsung melihat, mengamati, dan mencermati proses maupun keadaan yang ada pada objek penelitian yaitu LPK Terakoya Bali. Observasi dilakukan langsung baik sebelum, sesaat, dan setelah proses pembelajaran berlangsung. Observasi dalam penelitian ini dilaksanakan sampai mencapai jenuh data. Dalam kegiatan pembelajaran, apabila pada observasi pertama dan observasi kedua masih terdapat perbedaan cara mengajar guru dalam hal strategi yang digunakan, maka akan dilanjutkan dengan observasi yang ketiga, begitu seterusnya sampai tidak ada lagi perubahan cara mengajar guru.

Dalam metode wawancara, penulis melakukan tanya jawab secara langsung kepada pihak yang bersangkutan, untuk memperoleh data yang diperlukan. Peneliti menggunakan metode wawancara untuk menjawab masalah yang ada yaitu mengenai strategi serta metode pengajar dalam pembelajaran dan kendala yang dihadapi guru dalam proses pembelajaran. Pada penelitian ini, peneliti mengunakan menggunakan metode wawancara terstruktur dan terbuka, yaitu wawancara yang dilakukan dengan tidak merahasiakan informasi mengenai narasumbernya dan juga berpedoman pada daftar pertanyaan yang telah dipersiapkan sebelumnya.Dalam metode dokumentasi penulis mendokumentasikan buku pelajaran, data-data administrasi lembaga, dan foto-foto proses pembelajaran di LPK Terakoya Bali.

Instrumen penelitian adalah alat atau fasilitas yang digunakan oleh peneliti dalam mengumpulkan data agar pekerjaannya lebih mudah dan hasilnya lebih baik, dalam arti lebih cermat, lengkap, dan sistematis sehingga lebih mudah diolah (Arikunto,2006). Data yang diperlukan dalam penelitian ini adalah berupa data deskriptif kualitatif. Dalam penelitian ini, instrumen yang akan digunakan yaitu catatan harian dan pedoman wawancara.

Pedoman observasi digunakan sebagai acuan untuk mengetahui segala sesuatu yang berhubungan dengan objek penelitian secara langsung dan jelas tanpa perlu mengirangira. Observasi digunakan untuk memperoleh data tentang profil LPK Terakoya Bali. Dalam hal ini, peneliti melakukan observasi hingga data jenuh guna untuk mengetahui secara jelas bagaimana pembelajaran di LPK Terakoya, strategi pembelajaran yang digunakan, bahan ajar yang digunakan serta elemen pendukung lainnya dalam pembelajaran. Jenis observasi yang digunakan adalah observasi pastisipasi, pada observasi partisipasi peneliti ikut terlibat langsung dalam kegiatan pengamatan di lapangan. Pedoman wawancara digunakan sebagai acuan dalam melakukan wawancara langsung untuk memperoleh data tentang profil proses pembelajaran LPK Terakoya Bali. Dalam hal ini, peneliti melakukan wawancara untuk 
mempertegas hasil yang telah diperoleh melalui observasi. Pedoman wawancara memuat daftar pertanyaan yang nantinya ditanyakan dalam melakukan wawancara langsung.

Teknik deskriptif kualitatif adalah suatu teknik yang menganalisis data dengan cara menginterpretasikan data yang diperoleh dengan kata-kata. Teknik deskrptif kualitatif juga diartikan sebagai penelitian yang tidak mengadakan perhitungan atau hanya menggunakan kata-kata (Moloeng dalam Jobrohim (ed), 2001:23). Analisis data pada penelitian ini dilakukan secara deskriptif untuk data strategi yang digunakan dalam pembelajaran di LPK Terakoya Bali. Analisis data dalam penelitian ini mengikuti prosedur: (1) tabulasi data; (2) reduksi data; (3) deskripsi data, (4) klasifikasi data, dan (5) penarikan kesimpulan.Pada tahap tabulasi data, data yang didapatkan berdasarkan hasil observasi dan wawancara yang digabungkan berdasarkan strategi pembelajaran yang digunakan dalam proses pembelajaran, faktor-faktor yang mendasari penggunaan strategi tersebut dalam pembelajaran, kendala dalam pembelajaran bahasa Jepang yang terdapat pada LPK Terakoya Bali.Data yang diperoleh dari lapangan jumlahnya cukup banyak, untuk itu maka perlu dicatat secara teliti dan rinci. Seperti telah dikemukakan, makin lama peneliti ke lapangan, maka jumlah data makin banyak, kompleks dan rumit. Untuk itu perlu segera dilakukan analisis data melalui reduksi data. Mereduksi data berarti memilih hal-hal pokok, memfokuskan pada hal-hal yang penting, dicari temanya serta polanya, dan membuang yang tidak perlu (Sugiyono,2006:338). Apabila data yang didapatkan ternyata valid, maka data tersebut dapat dikumpulkan untuk diklasifikasikan. Sebaliknya, jika data yang didapatkan ternyata tidak valid, data tersebut harus dibuang. Dengan demikian data yang telah direduksi akan memberikan gambaran yang lebih jelas, dan mempermudah peneliti untuk melakukan pengumpulan data selanjutnya, dan mencarinya bila diperlukan (Sugiyono, 2014).

Penelitian ini menggunakan penyajian data dengan teks yang bersifat naratif. Data yang disajikan dalam penelitian ini berbentuk rangkuman secara deskriptif dan sistematis dari hasil yang diperoleh sehingga tema sentral dapat diketahui dengan mudah dan setiap rangkuman diberikan penjelasan dengan memperhatikan kesesuaian dengan fokus penelitian.Klasifikasi data merupakan proses pengelompokkan data dari data yang sudah tersusun rapi mejadi data yang tersusun berdasarkan kategori-kategori tertentu sesuai dengan tujuan penelitian. Pada klasifikasi data tergambar secara garis besar sebagai berikut.

1) Strategi pembelajaran bahasa Jepang di LPK Terakoya Bali,

2) Faktor-faktor yang mendasari penggunaan strategi tersebut oleh pengajar di LPK Terakoya Bali

3) Kendala-kendala yang dihadapi pengajar dalam pembelajaran bahasa Jepang di LPK Terakoya Bali.

Nasution (1992:116) menerangkan bahwa keuntungan menggunakan metode triangulasi ini adalah dapat mempertinggi validitas, mengukur kedalaman hasil penelitian sebagai pelengkap apabila data dari sumber pertama masih ada kekurangan. Agar data yang diperoleh itu semakin dapat dipercaya maka data yang diperoleh tidak hanya dicari dari satu sumber saja tetapi juga dari sumber-sumber lain yang terkait dengan subyek penelitian. Disamping itu, agar data yang diperoleh dapat lebih dipercaya maka informasi atau data yang diperoleh dari hasil wawancara dilakukan pengecekan lagi melalui pengamatan. Sebaliknya data yang diperoleh dari pengamatan juga dilakukan pengecekan lagi melalui wawancara atau menanyakan kepada responden.Triangulasi yang dipakai dalam penelitian ini adalah trianggulasi sumber data. Trianggulasi sumber dilakukan dengan cara mengecek data yang telah diperoleh melalui beberapa sumber (Sugiyono, 2012:127). Data dalam peneitian kualitatif dideskripsikan, dikategorisasikan, mana pandangan yang sama, yang berbeda, dan mana yang spesifik dari sumber yang ada. Dasar pertimbangannya adalah bahwa untuk memperoleh satu informasi dari satu responden perlu diadakan cross cek antara informasi yang satu dengan informasi yang lain sehingga akan diperoleh informasi yang benar-benar valid. Informasi yang diperoleh diusahakan dari narasumber yang betulbetul mengetahui permasalahan dalam penelitian Tujuan akhir trianggulasi ini adalah 
membandingkan informasi tentang hal yang sama yang diperoleh dari berbagai pihak agar ada jaminan tentang tingkat kepercayaan data. Cara ini juga dapat mencegah dari anggapan maupun bahaya subyektifitas.

\section{Hasil dan Pembahasan}

Hasil penelitian akan dipaparkan dalam tiga hal mendasar yang terkait dengan (1) strategi pembelajaran bahasa Jepang di LPK Terakoya Bali, (2) faktor yang mendasari penggunaan strategi tersebut oleh pengajar di LPK Terakoya Bali, (3) kendala yang dihadapi dalam pembelajaran bahasa Jepang di LPK Terakoya Bali. Dalam penelitian ini, proses pencarian data dilakukan sesuai dengan rancangan yang telah disusun sebelumnya. Data-data yang dibutuhkan dalam penelitian ini didapat melalui metode observasi, metode dokumentasi, dan metode wawancara. Metode observasi yang dilakukan dalam penelitian ini untuk mengamati proses pembelajaran dalam rangka mendapatkan data yang dicapai yaitu mengenai strategi pembelajaran bahasa Jepang di LPK Terakoya Bali. Metode wawancara untuk melengkapi data terhadap penggunaan buku ajar, media, dan kendala dalam pembelajaran bahasa Jepang. Selain itu, data akan diperkuat dengan adanya metode dokumentasi berupa silabus, hasil kerja siswa, dan foto dalam proses pembelajaran.Pada LPK Terakoya Bali terdapat tiga pengajar yang mengajar di kelas. Ketiga pengajar yang mengajar di kelas yaitu satu orang pengajar lulusan kependidikan, satu orang lulusan sastra Jepang dan satu orang mantan peserta magang yang sudah kembali setelah tiga tahun melakukan pemagangan di Jepang.

Observasi pertama dilakukan pada 20 mei 2018. Materi yang diberikan yaitu materi tata bahasa (bunpou) No.1 3 (〜です、じやないです、〜ではありません、〜ですか?はい・そうです・いいえ・ちがい ます). Sebelum memulai proses belajar mengajar di kelas, tenaga pendidik menyiapkan modul dan juga media yang akan digunakan untuk mengajar dikelas, sehingga proses belajar mengajar akan berlangsung dengan baik. Pada pembelajaran di hari pertama observasi ini, tenaga pendidik telah menyiapkan beberapa contoh karangan pendek yang akan diberikan kepada siswa guna mengetahui kemampuan membaca siswa.Observasi kedua dilakukan Pada 12 Juni 2018. Materi yang diberikan yaitu Materi No.82 84 (〜が好きです、どんな、〜が上手です) . Sebelum memasuki kelas, tenaga pendidik memeriksa kembali modul yang akan digunakan untuk memberikan materi pembelajaran kepada siswa, selain itu tenaga pendidik juga menyiapkan media yang akan digunakan dalam memberikan materi pada pembelajaran hari kedua ini.Observasi kedua dilakukan Pada 23 Juli 2018. Materi yang diberikan yaitu Materi tatabahasa/bunpou No.114 116 mengenai perubahan kata kerja potensial (〜できます、可能形)、dan materi (〜た事があります). Sebelum memasuki kelas dan memulai proses belajar mengajar, tenaga pengajar terlebih dahuli menyiapkan modul dan media yang akan digunakan pada proses belajar mengajar.Observasi keempat dilakukan pada 3 September 2018. Materi yang diberikan yaitu Materi (KB として〜) dan penggunaan partikel で. Sebelum memasuki kelas, tenaga pendidik memeriksa kembali modul yang akan digunakan untuk memberikan materi pembelajaran kepada siswa, selain itu tenaga pendidik juga menyiapkan media yang akan digunakan dalam memberikan materi pada pembelajaran hari keempat ini.

Data hasil wawancara dalam penelitian ini adalah data yang memuat kegiatan wawancara yang dilakukan penulis dengan pengajar bahasa Jepang di LPK Terakoya. Wawanncara dilakukan secara tidak berstruktur untuk memperoleh data awal sebelum melakukan observasi kelas. Wawancara kepada pengajar dilakukan disela-sela waktu istirahat atau diluar jam pelajaran. Hasil wawancara diperoleh dari ketiga pengajar yang mengajar bahasa Jepang di LPK Terakoya.

Dalam pembelajaran pada LPK Terakoya, pelatihan yang dilaksanakan yaitu khusus untuk pembelajaran bahasa Jepang, tidak ada bahasa lain lagi. Pelatihan ini diberikan kepada mereka yang berkeinginan untuk mencari pengalaman bekerja di Jepang maksimal selama 3 tahun dalam sekali pemagangan. Pembelajaran bahasa Jepang di LPK Terakoya ini 
dilaksanakan setiap hari senin sampai hari jumat yaitu sekitar 8 jam setiap harinya. Dalam proses pembelajarannya, tentu pengajar dan siswa menggunakan buku penunjang atau modul agar pembelajaran berjalan dengan baik dan lancar .Buku penunjang atau modul yang digunakan adalah modul yang disusun oleh para pengajar di LPK Terakoya Bali yang tentunya berpedoman dengan Silabus yang disusun oleh pengajar LPK Terakoya. Pada pembelajaran para pengajar tidak menggunakan RPP namun didalam silabus sudah lengkap adanya perencanaan pembelajaran hingga evaluasi pembelajaran yang akan diterapkan di kelas.

Berdasaran observasi penelitian mengenai profil strategi pembelajaran bahasa Jepang di lembaga pelatihan kerja Terakoya Bali, menemukan hasil bahwa ada dua strategi pembelajaran yang relevan untuk digunakan dalam pembelajaran di kelas. Strategi tersebut adalah drill, tanya jawab dan role playing.Strategi drill yang digunakan dalam latihan bisa mengacu kepada kegiatan bertanya dan menjawab antara siswa dengan pengajar ataupun latihan pengucapan yang dilakukan oleh siswa. Berdasarkan hasil observasi, siswa nampak aktif sehingga terjadi interaksi dua arah antara siswa dan pengajar. Strategi drill merupakan salah satu strategi yang cocok diterapkan untuk pembelajaran bahasa Jepang bagi calon tenaga kerja di LPK Terakoya. Strategi drill memudahkan siswa untuk memahami kosakata dan kalimat bahasa Jepang serta mampu menciptakan suasana kelas yang lebih kondusif.

Dalam pembelajaran bahasa Jepang di LPK Terakoya, siswa dituntut untuk mampu berbicara menggunakan bahasa target secara baik. Dalam pengajaran berbicara, latihan drill merupakan salah satu cara yang efektif digunakan untuk dapat mendorong siswa mendapat kesempatan berbicara dan meningkatkan keterampilannya. Siswa diharapkan mampu untuk mengucapkan pelafalan dengan benar dan jelas. Dengan strategi drill membuat siswa memahami materi yang sedang dibahas dan menimbulkan rasa percaya diri siswa dalam berbicara.

Dalam pembelajaran bahasa Jepang di kelas, pengajar tidak hanya menggunakan satu strategi. Strategi lain yang digunakan pengajar dalam memberikan pembelajaran bahasa Jepang di kelas yaitu strategi tanya jawab. Strategi tanya jawab ini digunakan untuk melatih penguasaan kosakata dan pola kalimat yang telah dipelajari siswa dan mengetahui seberapa jauh siswa mampu menguasai materi yang sudah diajarkan. Kegiatan tanya jawab dilakukan oleh pengajar kepada siswa dan siswa dengan siswa. Kegiatan ini dilakukan untuk melatih penggunaan kosakata dan pola kalimat yang telah diajarkan oleh pengajar.

Faktor yang mendasari penggunaan strategi drill dan tanya jawab pada saat pembelajaran yang dilaksanakan di LPK Terakoya bertujuan agar memudahkan siswa untuk mengingat kosakata dan pola kalimat bahasa Jepang dan siswa dituntut untuk mampu berbicara menggunakan bahasa target secara baik. Dalam mengembangkan kemampuan berbicara, menurut para pengajar latihan drill merupakan salah satu cara yang efektif digunakan untuk dapat mendorong siswa mendapat kesempatan berbicara dan meningkatkan keterampilannya.

Faktor yang menyebabkan digunakannya strategi tanya jawab dilakukan oleh pengajar kepada siswa dan siswa dengan siswa untuk melatih penggunaan kosakata dan pola kalimat yang telah diajarkan oleh pengajar. Kegiatan ini dapat dilihat pada observasi yang sudah dilakukan dimana pengajar selalu memulai pelajaran dengan bertanya kepada siswa mengenai materi yang sudah pernah diajarkan. Sedangkan kegiatan tanya jawab antar siswa bisa dilihat dari hasil observasi terakhir dimana siswa melalukan tanya jawab untuk melatih kemampuan mereka dalam menerapkan bahasa Jepang yang sudah dipelajari. Pada kegiatan tanya jawab diatas terjadi komunikasi secara langsung antara pengajar dengan siswa dan siswa dengan siswa.Faktor yang mendasari penggunaan strategi role play yaitu untuk meningkatkan keaktifan siswa, kreativitas, kerja keras dan kemampuan siswa dalam berkomunikasi menggunakan bahasa Jepang. Selain itu dari kegiatan role play ini siswa mampu melatih pengucapan/hatsuon bahasa Jepang yang baik dan membiasakan siswa untuk secara langsung menggunakan bahasa target di dalam sekolah maupun di luar sekolah. 
Dalam proses pengajaran terkadang terdapat kendala, hambatan atau masalah yang dihadapi pengajar. Hamalik (dalam Zulpah, 2012:33) terdapat 3 jenis faktor utama penyebab dari terjadinya hambatan tersebut, diantaranya: (1) faktor manusiawi, seperti: pengajar kurang mampu atau kurang berminat, siswa kurang mampu dalam mengikuti pelajaran, siswa berbeda satu sama lain. (2) Faktor institusional, seperti: terbatasnya ruang kelas, ruangan praktek laboratorium. (3) Faktor instruksional, seperti: terbatasnya alat peraga atau media pembelajaran. Kendala dalam konteks penelitian ini adalah hal-hal yang membatasi atau menghalangi pelaksanaan pembelajaran dalam proses pembelajaran bahasa Jepang dalam mencapai tujuan pembelajaran. Berdasarkan hasil observasi dan wawancara yang telah dilaksanakan, kendala pada pembelajaran di LPK Terakoya yaitu kendala mengenai kemampuan siswa yang berbeda-beda. Terdapat siswa yang mampu memahami materi secara cepat dan ada beberapa siswa yang kemampuan memahami materi tergolong lambat. Selain itu, dengan jenjang waktu yang tergolong singkat yaitu selama empat bulan, siswa benar-benar dituntut untuk mampu menguasai materi secara cepat. Oleh karena itu pengajar menemukan kendala saat penerapan strategi latihan/drill dan tanya jawab dilakukan dan juga tuntutan untuk menguasai materi secara cepat, berpengaruh terhadap rasa percaya diri siswa yang kemampuannya kurang dalam menguasai materi. Sehingga keberanian mereka untuk berbicara hilang.

Hal yang dilakukan untuk mengatasi kendala-kendala tersebut yaitu dengan memberikan tugas menghafal kosakata, membuat karangan dan percakapan berbahasa Jepang yang akan di praktekan didepan kelas. Dari tugas yang diberikan tersebut, pengajar mampu menyiasati kendala siswa yang kehilangan kepercayaan diri dalam berbicara. Karena tugas tersebut menuntut siswa untuk setiap hari melatih diri untuk menerapkan kosakata dan pola kalimat bahasa Jepang yang sudah diajarkan dan menuntut siswa untuk melatih kemampuan mereka dalam berbicara menggunakan bahasa Jepang. Hal ini dilakukan setiap hari agar kemampuan mengingat dan berbicara siswa meningkat. Sehingga siswa terbiasa melatih diri untuk menerapkan bahasa jepang saat berada di sekolah maupun di luar sekolah dan juga siswa akan terbiasa menerima pembelajaran dengan strategi yang diterapkan oleh pengajar.

\section{Simpulan dan Saran}

Berdasarkan hasil analisis dan pembahasan terhadap profil pembelajaraan bahasa Jepang di LPK Terakoya, Bali dapat disimpulkan sebagai berikut

1. Strategi pembelajaran yang digunakan Pengajar dalam pembelajaran bahasa Jepang di LPK Terakoya yaitu strategi dengan drill atau latihan, kemudian strategi dengan tanya jawab dan role play.

2. Faktor yang mendasari penggunaan strategi drill, tanya jawab dan role play pada saat pembelajaran yang dilaksanakan di LPK Terakoya guna memudahkan siswa untuk memahami dan mengingat kosakata, pola kalimat bahasa Jepang dan juga siswa dituntut untuk mampu berbicara menggunakan bahasa target secara baik.

Dalam pengajaran berbicara, latihan drill merupakan salah satu cara yang efektif digunakan untuk dapat mendorong siswa mendapat kesempatan berbicara dan meningkatkan keterampilannya. Faktor yang menyebabkan digunakannya strategi Tanya jawab dilakukan oleh pengajar kepada siswa dan siswa dengan siswa untuk melatih penggunaan kosakata dan pola kalimat yang telah diajarkan oleh pengajar. Kegiatan ini dapat dilihat pada observasi yang sudah dilakukan dimana pengajar selalu melakukan tanya jawab dengan siswa untuk memastikan siswa sudah memahami materi yang sudah diajarkan. Pada kegiatan tanya jawab diatas terjadi komunikasi secara langsung antara pengajar dengan siswa. Pengajar ingin mengetahui sampai sejauh mana pemahaman siswa terhadap materi yang dijelaskan dengan bertanya untuk mendapatkan respon secara langsung dari siswa. Sedangkan penggunaan role play dilakukan untuk melatih kemampuan siswa dalam mengembangkan kosakata dan pola kalimat yang sudah dipelajari serta melatih pengucapan/hatsuon siswa dalam berkomunikasi menggunakan bahasa Jepang dengan baik. 
3. Kendala dalam konteks penelitian ini adalah hal-hal yang membatasi atau menghalangi pelaksanaan pembelajaran dalam proses pembelajaran bahasa Jepang dalam mencapai tujuan pembelajaran.

Kendala pada pembelajaran di LPK Terakoya yaitu kendala mengenai kemampuan siswa yang berbeda-beda. Dan dengan jenjang waktu yang tergolong singkat yaitu selama empat bulan, siswa benar-benar dituntut untuk mampu menguasai materi secara cepat.

Hal yang dilakukan untuk mengatasi kendala tersebut yaitu dengan memberikan tugas menghafal kosakata, membuat karangan dan percakapan berbahasa Jepang yang akan di praktekan didepan kelas.

\section{Daftar Pustaka}

Arikunto. 1998. Prosedur Penelitian. Jakarta: PT. Rineka Cipta

Arikunto. 2006. Metode Penelitian Kualitatif. Jakarta: Bumi Aksara

Baroroh. 2011. "Upaya Meningkatkan Nilai-Nilai Karakter Peserta Didik Melalui Penerapan Metode Role Playing". Jurnal Ekonomi dan Pendidikan, Volume 8, Nomor 2.

David, J.R. 1976. Teaching Strategies for College Classroom, P3G.

Destiari, santie. 2017. "Metode Dediscerta Meningkatkan Kemampuan Membaca Pemahaman Siswa", Jurnal Pendidikan dan Pengajaran Bahasa Jepang, Volume 2, Nomor 1, ISSN:2528-5548

Hamalik, Oemar. 2001. Proses Belajar Mengajar. Jakarta: Bumi Aksara

Kedrayati, Akanisi. 2012. "Non-Formal Education: It Is Relevant or Obsolete?". International Journal of Business, Humanities and Technology, Vol. 2 No. 4. Pp 11-15.

Nguyen, 2017. "Students Attitudes Towards Drama Based Role Play In Oral Performance". European Journal of Foreign Language Teaching, Volume 2.

Parera, J. D. 1993. Leksikon Istilah Pembelajaran Bahasa. Jakarta: Erlangga.

Roestiyah.2001. Strategi Belajar Mengajar. Jakarta: Rineka Cipta.

Sanjaya, Wina. 2008. Perencanaan dan Desain Sistem Pembelajaran. Jakarta: Kencana Predana Media Group.

Soelaiman Joesoef. (1992). Konsep Dasar Pendidikan non formal. Jakarta: Bumi Aksara.

Soelaiman Joesoef. 2008. Konsep Dasar Pendidikan Luar Sekolah. Jakarta: Bumi Aksara.

Sugiyono. 2009. Metode Penelitian Pendidikan. Bandung: ALFABETA.

Sugiyono. 2014. Metode Penelitian Pendekatan Kualitatif, Kuantitatif, dan R\&D. Bandung: ALFABETA.

Undang- Undang No. 20 Tahun 2003 tentang Sistem Pendidikan Nasional

Wendra, Wayan. 2013. Penulisan Karya IImiah. Singaraja: Undiksha. 